\title{
27 補助人工心荗使用症例の遠隔成績
}

村上泰治，新太喜治（岡山大中央手術部）

中山裕宣, 入江博之, 妹尾嘉昌, 寺本 滋 (岡山大第二外科)

過去 4 年間に 10 例に補助人工心藏（VA D) を用い た. 男 5 , 女 5 例で, 年齢は 22 から 66 歳, 平均 51 藏で ある. 診断は弁膜症 $6, \mathrm{AAE} 2$, 心筋梗塞 2 例で, 手術はDVR 4, AVR 3, Cabrol 手術 1, 冠動脈 バイパス術 2 例で岁る.VA D適用理由は人心肺離 脱不能 9 例, 術後心原性ショック 1 例である. 8 例化 左心バイパス，1例に右バイパス，1例に両心バイパ スを行ったＶVADはダイアフラム型と遠心ポンプを 用いた。補助循環時間は 6 時間から 9 日, 平均 4.8 日 であった，10例中 9 例がV A D から離脱し，5例が生 存, 退院した. 生存 5 例はすべて升膜症で, 追跡期間
は13から33カ月, 平均22カ月である. NYHA 機能分 類では術前IV度 3 , 皿度 2 例で, 術後は I 度 4 , II度 1 例であった. 術前と術後 1 年で心ェューによる心機 能検查を行い，さらに自転車エルゴメーターによる運 動負荷を行った。

CO, mVcf， EF，LVDs を計測すると EF，LVDs が衍後有意に上昇したが，運動負荷では有意な変化が みられなかった。

以上より V A D 症例は術後心機能の改善がみられた が，耐運動能では十分な回復を得られなかった。

\section{8 心臓外科手術中における電磁血流計の使用経験}

\author{
井上健治（国立山口病院放射線科） \\ 須磨幸蔵（東京女子医大第二病院心臓血管外科） \\ 辻 隆之 (東京医科歯科大医器材研)
}

成人の大動脈弁人工弁置換術において，最小いくら のサイズの人工弁が必要か問題のあるところである. 手術中に電磁血流計を用いて人工升のもつ狭窄の流体 力学的評価を和こなった。

〈対象並びに方法〉成人の後天性大動脈弁疾患 9 例 で㐫る. 全例 St. Jude Medical 弁 (SJM 弁) を用 いたが，21mm 使用群 (I 群) の平均年齢 $50.8 \pm 12.5$ 歳, $23 \mathrm{~mm}$ 使用群 (II群) のそれは 53.8土13.1 歳. 計 測は手術室で括こなった. 電磁血流計のカフ式プロー ブを大動脈起始部に装着して血流量を測定し，また心 拍出量も測定した.このブローブ内径を大動径とし， またピーク流速を求めた。左室大動脈間ピーク圧差を $\Delta \mathrm{p}$ とし，血流密度 $\boldsymbol{\rho}$ は一定とした.これらより玨力 損失係数入を求めた。ささらにこの入を才りフィスの断 面積比狭窄度で表示した。

〈結果〉大動脈ピーク流量は $23 \mathrm{~mm}$ 縫着群が $8.5 \%$
多かったけれども両群間に有意差はなかった。大動脈 最大流速は $23 \mathrm{~mm}$ 縫着群が $9.6 \%$ 速い流速を示したが， 両群間に有意差はなかった. 左室大動脈収縮期圧差は $21 \mathrm{~mm}$ 释着群が $16 \%$ 大きい圧差を示したが，両群間に 有意差はなかった. 圧力損失係数 ( $\lambda$ ）は $21 \mathrm{~mm}$ 縫着 群が 13\% 大きい値を示したが，両群間に有意差はな かった. オリフィス狭窄の程度に換算すると, $21 \mathrm{~mm}$ 縫着群が $72 \%$ であって, $23 \mathrm{~mm}$ 縫着群より $5.6 \%$ 狭窄 の程度が強かった.

〈結語〉大動弁位 S J M弁 $21 \mathrm{~mm}, 23 \mathrm{~mm}$ 縫着群の断 面積比狭窄度は，各々平均で $72 \% ， 68 \%$ であった。 従来臨界狭窄は 75\% とされているので, 通常の心拍 出量下ではこの抵抗は許容できると考えられた。かく の如く心臓外科手術中における電磁血流計の使用は有 用之考えられた。 